Proc. Estonian Acad. Sci. Geol., 1997, 46, 2, 93-104

\title{
METABENTONITE COMPOSITION RELATED TO SEDIMENTARY FACIES IN THE LOWER SILURIAN OF ESTONIA
}

\author{
Tarmo KIIPLI, Enli KIIPLI, and Toivo KALLASTE
}

Institute of Geology, Estonia Blvd 7, EE-0001 Tallinn, Estonia; e-mail: ptrgi@teleport.ee

Received 9 December 1996, accepted 10 April 1997

\begin{abstract}
Llandovery and Wenlock altered volcanic ash layers, metabentonites, of Estonia were investigated using X-ray diffractometry and X-ray fluorescence methods. Large-scale compositional variations, ranging from almost pure $\mathrm{K}$-feldspar, illite-smectite or kaolinite to different mixtures of these minerals, $\mathrm{K}_{2} \mathrm{O}$ contents from 3.6 to $15.3 \%$, and $\mathrm{Al}_{2} \mathrm{O}_{3}$ from 18 to $31 \%$, show great differences from source pyroclastic material. There is a distinct relationship between the metabentonite composition and Silurian shelf sea facies. The presence of kaolinite in deep shelf facies proves low $\mathrm{pH}$ (below 7.4) conditions near the sea floor. On the shallow shelf area K-feldspar (low sanidine) formed; accordingly, sea water was more alkaline ( $\mathrm{pH} 7.8-8.2)$, like in present-day sea.
\end{abstract}

Key words: metabentonite, authigenic silicates, Lower Palaeozoic, facies, diagenesis.

\section{INTRODUCTION}

East Baltic and Scandinavian Palaeozoic volcanic tephra layers, metabentonites (MBs, also K-bentonites or bentonites in many papers), have been investigated for correlation over large areas, the search for the location of source volcanoes, and the determination of original magma composition (Vingisaar, 1972; Bergström et al., 1992, 1995). The mineralogical and chemical composition of MB has been investigated by Byström (1956, 1957), Jürgenson (1958a, 1964, 1988), Lapinskas (1965), Utsal \& Jürgenson (1971), Vingisaar \& Murnikova (1973), Snäll (1978), Velde \& Brusewitz (1982), Brusewitz (1986), Kepezhinskas et al. (1994).

The main characteristic feature of Palaeozoic MBs is their illite-smectite mixed-layer composition; less commonly kaolinite or illite prevail. Besides illitesmectite, an almost pure K-feldspar composition has been recorded from North America (Hay et al., 1988) and Estonia (Kiipli \& Kallaste, 1996). Chemical analyses revealed high potassium, aluminium, and low silica and sodium contents 
compared to potential source pyroclastics and host rock terrigenous material. The main mineralogical characteristics distinguishing $\mathrm{MB}$ from the fine-grained terrigenous material of the host rock are: 1 . Presence of illite-smectite and kaolinite instead of illite common in Ordovician and Silurian sections (although in some MBs illite containing less than $15 \%$ of smectite layers has been recorded; Utsal \& Jürgenson, 1971; Velde \& Brusewitz, 1982). 2. Low content or absence of quartz. 3. Low content or absence of carbonate minerals. 4. Sometimes a high content of authigenic $\mathrm{K}$-feldspar (low-sanidine). 5. Presence of visually detectable biotite flakes. 6. Commonly absence of chlorite. 7. Presence of zircon and apatite.

Mineralogical and chemical compositional variations may be explained by either recrystallization in hydrothermal or thermal processes (Brusewitz, 1986; Hay et al., 1988) or low grade metamorphism (Velde \& Brusewitz, 1982). Other investigators explained lateral variations in the composition as a result of different distances from source volcanoes (Utsal \& Jürgenson, 1971; Vingisaar \& Murnikova, 1973). In this paper we show that, besides other factors, the compositional variations of MBs depend on facies and early diagenetic conditions in the Early Palaeozoic continental shelf.

\section{ORIGINAL MAGMA COMPOSITION AND EXTENT OF DIAGENETIC CHANGE}

Great changes in the concentration of initial elements of the volcanic substance - $\mathrm{Al}$ enrichment, $\mathrm{Si}$, Na depletion, $\mathrm{K}$ absorption from sea water, and $\mathrm{Nb}, \mathrm{Y}, \mathrm{Zr}$, and $\mathrm{Ti}$ enrichment-depletion - led to the conclusion that absolute values of immobile element contents should be used with caution to determine the source magma; instead element ratios would be applied (Kiipli \& Kallaste, 1996). In the present paper the original magma composition for 36 Estonian MBs was restored according to $\mathrm{Zr} / \mathrm{TiO}_{2}$ ratios (Winchester \& Floyd, 1977). As a result the range of the subalkaline suite from andesite to rhyolite was ascertained (Fig. 1). The presence of felsic source magma is not probable as $\mathrm{Nb}$ contents are fivefold lower than typically recorded for these rocks (compare Kiipli \& Kallaste, 1996 and Winchester \& Floyd, 1977).

Different types of MB minerals and assemblages, such as K-feldspar, K-feldspar with illite-smectite, illite-smectite, kaolinite with illite-smectite, do not associate with one certain type of original magma composition (Fig. 1). Thus, the source magma composition is not the decisive factor in forming the MB composition.

The extent of the diagenetic change could be estimated comparing the content of almost insoluble $\mathrm{Al}$ in $\mathrm{MBs}$ with $\mathrm{Al}$ in source magma, restored by the ratio of immobile trace elements (Fig. 1). Acidic tephra has generally gone through a more profound mass change than andesite and dacite. In kaolinitic MBs the loss of mass was 2.5 times. 


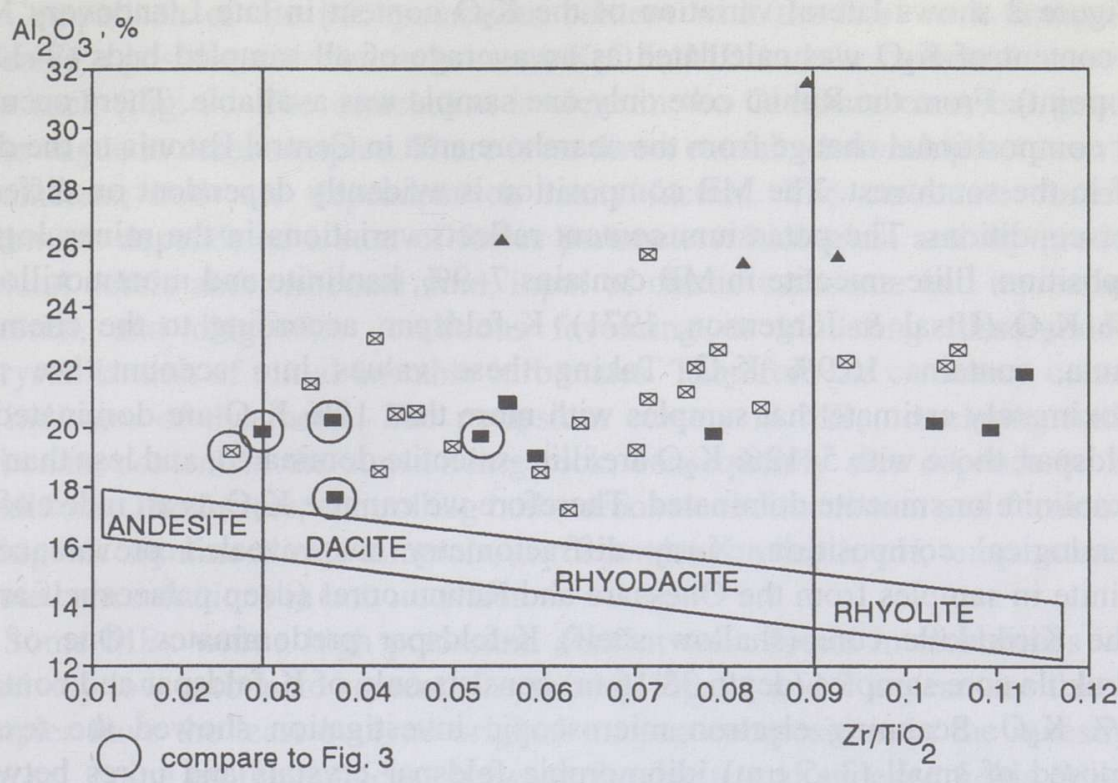

- K-feldspar mainly, $\otimes$ illite-smectite, $\quad \Delta$ kaolinite mainly

Fig. 1. The diagram showing diagenetic changes in the mass of pyroclastic sediment. $\mathrm{The} \mathrm{Zr} / \mathrm{TiO}{ }_{2}$ ratio refers to original magma composition. The position of supposed source magma in the diagram is marked by the rock name. Insoluble $\mathrm{Al}_{2} \mathrm{O}_{3}$ content in metabentonite compared with source volcanic material shows changes in the mass during dissolution-recrystallization processes. Circles mark samples with an anomalously high potassium content in Fig. 3.

\section{LATERAL COMPOSITIONAL VARIATIONS AND RELATIONS TO FACIES}

Jürgenson (1958a, 1964) noted that Caradoc and Silurian MBs in western Estonia are plastic and expandable, but in the eastern part of Estonia these layers are represented by hard nonplastic material containing free silica and more potassium. She recorded the same lithological variation in a vertical section of single beds. Later Utsal \& Jürgenson (1971), and Vingisaar \& Murnikova (1973) explained east-west extending compositional variations with differences in the distances from source volcanoes. According to a palaeogeographic reconstruction, Caledonian volcanoes were situated west from Estonia (Jürgenson, 1962; Vingisaar, 1972). In the Lower Silurian of Lithuania Lapinskas (1965) described the relationship between facies and number of MB beds: deep-water black shales contain many $\mathrm{MB}$ beds, intermediate-depth marlstones less, and shallow-water limestones no MB. 
Figure 2 shows lateral variation of the $\mathrm{K}_{2} \mathrm{O}$ content in late Llandovery MB. The content of $\mathrm{K}_{2} \mathrm{O}$ was calculated as an average of all sampled beds (2-12 in each point). From the Ruhnu core only one sample was available. There occurs a clear compositional change from the nearshore area in Central Estonia to the deep shelf in the southwest. The MB composition is evidently dependent on different facies conditions. The potassium content reflects variations in the mineralogical composition. Illite-smectite in MB contains 7-9\%, kaolinite and montmorillonite $1-2 \% \mathrm{~K}_{2} \mathrm{O}$ (Utsal \& Jürgenson, 1971). K-feldspar, according to the chemical formula, contains $16.9 \% \mathrm{~K}_{2} \mathrm{O}$. Taking these values into account, we may approximately estimate that samples with more than $12 \% \mathrm{~K}_{2} \mathrm{O}$ are dominated by $\mathrm{K}$-feldspar, those with 5-12\% $\mathrm{K}_{2} \mathrm{O}$ are illite-smectite dominated, and less than $5 \%$ are kaolinite or smectite dominated. Therefore we can use $\mathrm{K}_{2} \mathrm{O}$ as an index of the mineralogical composition. X-ray diffractometry has revealed prevalence of kaolinite in samples from the Ohesaare and Ruhnu cores (deep palaeoshelf area). In the Kirikuküla core (shallow shelf) K-feldspar predominates. One of the Kirikuküla core samples (depth $38.16 \mathrm{~m}$ ) consists only of K-feldspar and contains $15.3 \% \mathrm{~K}_{2} \mathrm{O}$. Scanning electron microscopic investigation showed the texture composed of small $(3-5 \mu \mathrm{m})$ idiomorphic feldspar crystals and pores between them. Samples from the Viki core (area of intermediate depth) consist of illitesmectite with some K-feldspar.

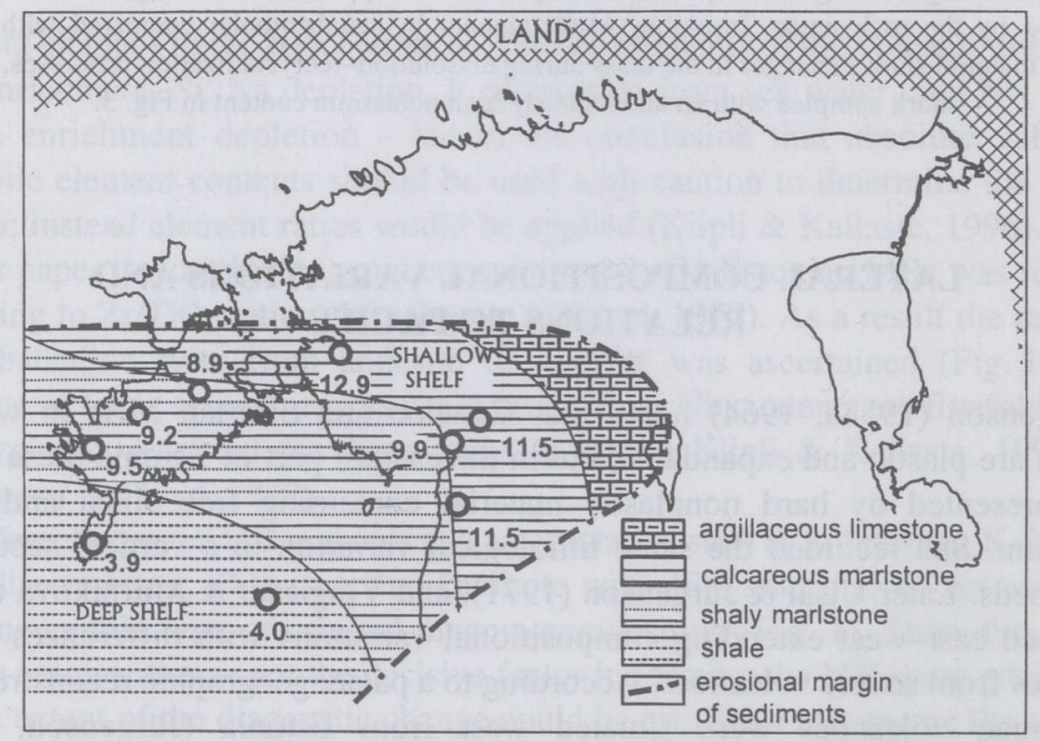

Fig. 2. Lateral changes in the $\mathrm{K}_{2} \mathrm{O}$ content (\%) of metabentonites in the facies framework of the late Llandovery. Facies are presented after Jürgenson (1966). $\mathrm{K}_{2} \mathrm{O}$ contents are from Jürgenson (1964) and Kiipli \& Kallaste (1996). Circles mark the location of boreholes and numbers show average $\mathrm{K}_{2} \mathrm{O}$ contents $(\%)$ in metabentonite beds. 
Comparison of the $\mathrm{MB}$ potassium content with the host rock composition revealed a positive correlation between $\mathrm{K}_{2} \mathrm{O}$ in $\mathrm{MB}$ and the carbonate content in host rock (Fig. 3). The correlation is clear in the Ohesaare core, but generally quite vague in other samples. There is no direct causal relationship between these parameters; both are dependent on many factors. The carbonate content in sediments depends on a sum of facies parameters: biological activity producing skeletal debris and carbonate mud, input of clastic carbonate and noncarbonate material, and diagenetic conditions favouring or hindering dissolution and recrystallization of initial unstable carbonates. Therefore the carbonate content is an indicator of the facies. The potassium content in $\mathrm{MB}$, correlating with the carbonate content in the surrounding rock, consequently also depends on facies conditions. The factors, controlling both carbonate sedimentation and formation of authigenic aluminosilicate minerals, are dependent on depth, $\mathrm{pH}$, temperature, and solute concentrations in bottom water.

Some MBs with a high potassium content were found in marlstones with a relatively low carbonate content. Comparing Figs. 1 and 3 we can see that these samples have the least evolved original magma composition in the investigated data set, being on the boundary between the dacite and andesite fields (Viki and Kirikuküla cores, upper Llandovery). These MB samples are characterized by

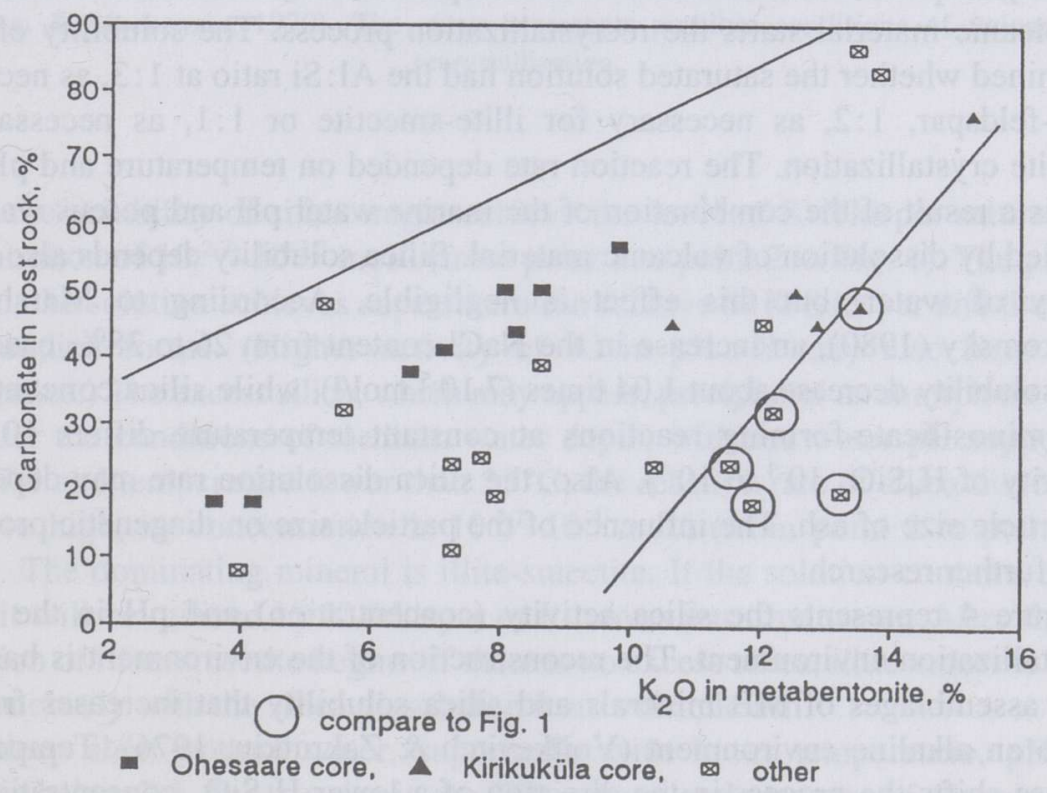

Fig. 3. The relation between potassium in metabentonite and carbonate in host rock. Circles mark samples with a high $\mathrm{K}_{2} \mathrm{O}$, Sr, and $\mathrm{Ni}$ content. 
higher $\mathrm{Sr}$ and Ni values (Sr 162-375 ppm and Ni 60-150 ppm), which also indicates the more basic composition of source magma. Remarkably andesites commonly contain less potassium than dacites and rhyolites. A high potassium content in these MBs is possibly caused by the alkaline environment created by the dissolution of abundant $\mathrm{Ca}$ and $\mathrm{Mg}$ in diagenesis. These data show that, besides facies conditions, source magma also had some influence on the final composition of the altered tephra.

\section{pH AND TEMPERATURE OF AUTHIGENIC SILICATE FORMATION}

The diagrams by Helgeson \& Mackenzie (1970), shown in Fig. 4, for equilibrium phase relations among aluminosilicate minerals and sea water in an idealized model of the ocean system at $25^{\circ} \mathrm{C}$ and $0{ }^{\circ} \mathrm{C}, 1 \mathrm{~atm}$., and in the logarithmic scale of $\mathrm{H}_{4} \mathrm{SiO}_{4}$ activity vs $\mathrm{pH}$, give a good framework for estimating the conditions of the reactions forming MB mineralogy. This process depends on the kinetics of volcanic vitric ash hydrolysis and mineral crystallization. Unstable amorphous vitric glass dissolution proceeds at higher rates than crystallization of minerals with ordered structures. The difference between the dissolution rate and the mineral precipitation rate creates a mineral supersaturation. Dissolution of Si from the volcanic material starts the recrystallization process. The solubility of silica determined whether the saturated solution had the $\mathrm{Al}$ : Si ratio at $1: 3$, as necessary for K-feldspar, $1: 2$, as necessary for illite-smectite or $1: 1$, as necessary for kaolinite crystallization. The reaction rate depended on temperature and $\mathrm{pH}$. The latter is a result of the combination of the marine water $\mathrm{pH}$ and porous water $\mathrm{pH}$ modified by dissolution of volcanic material. Silica solubility depends also on the salinity of water, but this effect is negligible. According to Marshall \& Warakomsky (1980), an increase in the $\mathrm{NaCl}$ content from 26 to $38 \%$ causes the silica solubility decrease about 1.04 times $\left(7 \cdot 10^{-5} \mathrm{~mol} / \mathrm{l}\right)$, while silica concentration in aluminosilicate-forming reactions at constant temperature differs 10 times (molarity of $\mathrm{H}_{4} \mathrm{SiO}_{4} 10^{-3}$ to $10^{-4}$ ). Also, the silica dissolution rate may depend on the particle size of ash. The influence of the particle size on diagenetic processes needs further research.

Figure 4 represents the silica activity (concentration) and $\mathrm{pH}$ in the tephra recrystallization environment. The reconstruction of the environment is based on actual assemblages of MB minerals and silica solubility that increases from an acid to an alkaline environment (Voitkevitch \& Zakrutkin, 1976). Temperature decrease shifts the process in the direction of a lower $\mathrm{H}_{4} \mathrm{SiO}_{4}$ concentration and higher $\mathrm{pH}$.

The possible scenario of mineral formation could be as follows. In slightly alkaline conditions of the shallow water with a temperature near $25^{\circ} \mathrm{C}$ and $\mathrm{pH} 7.8$ 


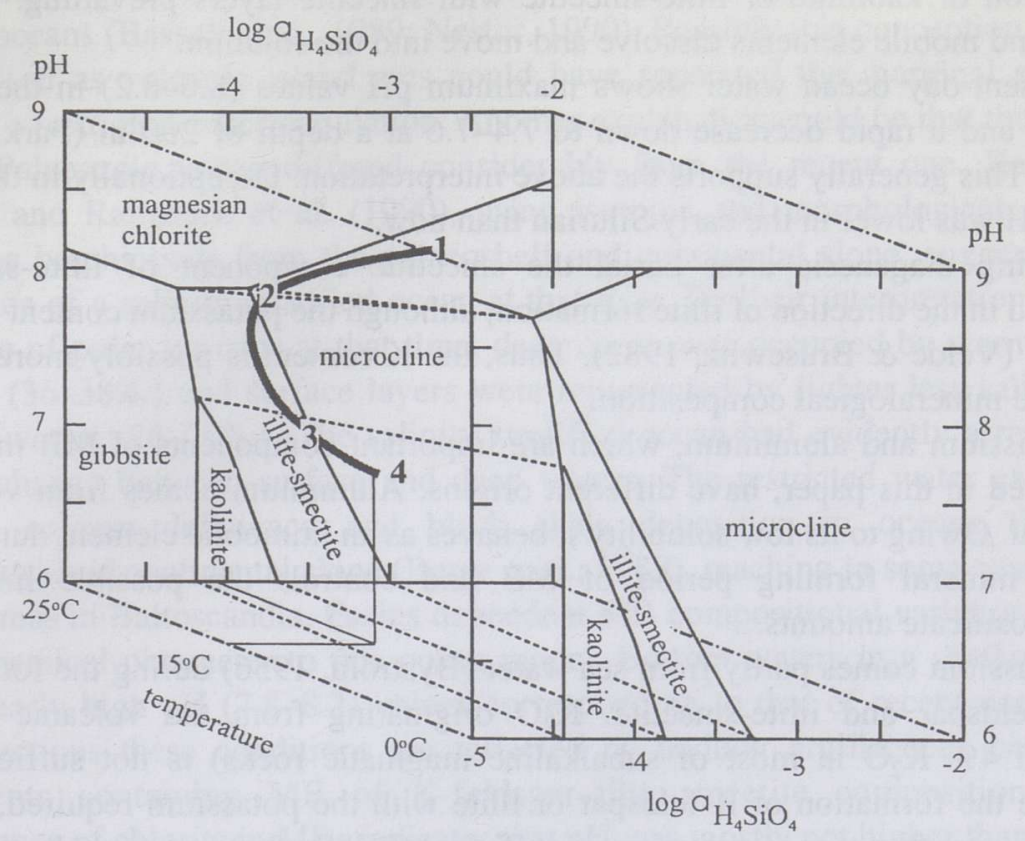

Fig. 4. Chemical equilibria diagram of aluminosilicate formation in sea water between 25 and $0{ }^{\circ} \mathrm{C}$ (Helgeson \& Mackenzie, 1970). The curve represents possible conditions of volcanic ash recrystallization.

to 8.2 , the solubility of silica might achieve the level of K-feldspar saturation concentration of $10^{-2.7}-10^{-3.7} \mathrm{~mol} / \mathrm{l}$ (from point 1 to point 2 in Fig. 4). The process is rapid, the solution achieves supersaturation relative to $\mathrm{K}$-feldspar and therefore low sanidine forms. (Higher activity of $\mathrm{Al}$ in $\mathrm{pH}>8$ may also have some significance.) The excess silica, which may appear, precipitates as amorphous silica.

Under the conditions of medium water depth, with sea water $\mathrm{pH}$ supposedly 7.5 to 7.8 and temperature lower than $25^{\circ} \mathrm{C}$, the reaction rate of silica dissolution is not so high, its concentration is $10^{-3.7}-10^{-4} \mathrm{~mol} / \mathrm{l}$ (from point 2 to point 3 in Fig. 4). The dominating mineral is illite-smectite. If the solution contains excess silica, it will be utilized by K-feldspar or it moves into free water. After that the formation of illite-smectite begins. If there is no excess silica, illite-smectite forms simultaneously with the silica dissolution from volcanic ash.

In deep shelf bottom water, supposedly with lower temperature, $\mathrm{pH}$ may decrease below 7.4, due to a rise in the $\mathrm{CO}_{2}$ content and presence of organic acids. These conditions favour kaolinite formation. Silica solubility in such an environment is low, supposedly $10^{-4.1} \mathrm{~mol} / \mathrm{l}$ (from point 3 to point 4 in Fig. 4) and the mineral crystallization process is slow, so the solution is saturated only for the 
formation of kaolinite or illite-smectite with smectite layers prevailing. Excess silica and mobile elements dissolve and move into the solution.

Present-day ocean water shows maximum $\mathrm{pH}$ values (8.0-8.2) in the upper $100 \mathrm{~m}$, and a rapid decrease down to 7.4-7.6 at a depth of $200 \mathrm{~m}$ (Park, 1966, 1968). This generally supports the above interpretation. Exceptionally in the deep shelf $\mathrm{pH}$ was lower in the early Silurian than now.

During diagenesis after burial the smectitic component of illite-smectite changed in the direction of illite formation, although the potassium content did not change (Velde \& Brusewitz, 1982). Thus, the $\mathrm{K}$ content is possibly more stable than the mineralogical composition.

Potassium and aluminium, which are important components of $\mathrm{MB}$ minerals discussed in this paper, have different origins. Aluminium comes from volcanic material. Owing to its low solubility it behaves as an immobile element during the whole mineral forming period of $\mathrm{MB}$ and controls the possible limits of aluminosilicate amounts.

Potassium comes partly from sea water (Byström, 1956) during the formation of $\mathrm{K}$-feldspar and illite-smectite. $\mathrm{K}_{2} \mathrm{O}$ originating from the volcanic source (around $4 \% \mathrm{~K}_{2} \mathrm{O}$ in most of subalkaline magmatic rocks) is not sufficient to provide the formation of $\mathrm{K}$-feldspar or illite with the potassium required, but in marine water the store of potassium is sufficient $(0.387 \mathrm{~g} / \mathrm{kg})$ and could be supplied by diffusion from sea water into sediment.

\section{DISCUSSION}

As thermodynamic calculations (Helgeson \& Mackenzie, 1970) have shown, authigenic silicates with different mineral and chemical compositions formed in environments with different $\mathrm{pH}$. On the other hand, $\mathrm{MB}$ composition is clearly related to palaeomarine facies reflected in host rock compositions. Chertification of rocks below and not above the MB (Hageman \& Spjeldnaes, 1955; Byström, 1956; Jürgenson, 1958a, 1958b, 1977; Laufeld \& Jeppsson, 1976; Grim \& Güven, 1978) proves the occurrence of large-scale dissolution and recrystallization processes before burial, therefore taking place in equilibrium with sea water. Another proof for very early diagenetic recrystallization is the idiomorphic shape of authigenic K-feldspar crystals and porous crystal supported texture. This suggests crystal formation in a water-saturated environment in a precompaction period. Therefore it is plausible that $\mathrm{MB}$ compositional features should reflect chemical characteristics of bottom water in the palaeosea. Low-potassium kaolinitic or smectitic MB in the deep shelf area seems to prove that low $\mathrm{pH}$ conditions (near 7) prevailed in bottom water, which is rather different from modern open shelf areas. Only in modern closed basins like the Baltic Sea pH 7 is recorded (Manheim, 1961). According to the present palaeogeographic 
reconstruction, in the Silurian time the Baltic shelf was open to the Iapetus and Rheic oceans (Bassett et al., 1989; Nestor, 1990). Possibly this conception should be revised as volcanic island arcs could have separated the marginal sea and caused a restricted water circulation. Another explanation could be that the whole Early Palaeozoic ocean differed considerably from the recent one. Railsback (1990) and Railsback et al. (1990), using isotopic and morphological data of Caradoc brachiopods from the palaeoshelf and continental slope, suggested the existence of a salinity stratified ocean at that time. By their interpretation, in the absence of polar ice caps at that time, deep ocean was occupied by warm saline waters (36-38\%o) and surface layers were represented by lighter less saline and colder waters (26-29\%o). The salinity stratified ocean had evidently a restricted water change between surface and deep waters. The restricted water exchange caused oxygen deficiency and black shale deposition in oceans (Poland, Germany) and continental slope (Berry et al., 1989), reaching in some cases deep shelf areas in Baltoscandia. Facies dependent MB compositional variations add a new chemical parameter to this ocean model. Bottom waters in a shallow shelf had clearly high $\mathrm{pH}(7.8-8.2)$ values corresponding to that of recent oceans. In rock sections these conditions are reflected by nodular argillaceous carbonate sediments containing $\mathrm{MB}$ of $\mathrm{K}$-feldspar-illite-smectite composition. Rare occurrence of chlorite in MBs indicates that $\mathrm{pH}$ was mostly not higher than 8.2. In present-day oceans $\mathrm{pH}$ values 8.2-8.4 are typical only of surface waters with high phytoplankton productivity. Deep shelf bottom waters had lower $\mathrm{pH}$ (below 7.4). These areas are represented by shales and marls with a low carbonate content and kaolinitic or smectitic MB.

\section{CONCLUSIONS}

1. Lower Silurian altered volcanic ash layers in sedimentary rocks from Baltoscandia have varied mineral and chemical compositions (illite-smectite, kaolinite, $\mathrm{K}$-feldspar, and mixtures of these minerals in different proportions). These differ considerably from the original source magma composition.

2. Compositional variations are clearly related to facies conditions on palaeoshelf sea (indicated by host rock composition) and are caused by the dissolution-recrystallization processes of initial unstable vitric material mainly on the seafloor, to a lesser extent after the burial. In some cases remarkable influence of the original magma composition on the final MB composition can be detected.

3. A K-feldspar illite-smectite assemblage in shallow shelf sediments could be interpreted as a reflection of normal marine conditions with $\mathrm{pH} 7.8-8.2$. The kaolinite-illite-smectite assemblage in deep shelf sediments possibly records lower $\mathrm{pH}$ (below 7.4) in the near-bottom water. As the Baltic basin has been interpreted as a sea freely open to the ocean, we may conclude that the vertical $\mathrm{pH}$ profile in the palaeo-ocean was different from that in recent oceans. 
We thank D. Kaljo, E. Pirrus, E. Jürgenson, and J. Winchester for constructive criticisms of earlier drafts of this paper. Financial support was provided by ESF grant 2651.

\section{REFERENCES}

Bassett, M. G., Kaljo, D. \& Teller, L. 1989. The Baltic region. In A Global Standard for the Silurian System (Holland, C. H. \& Bassett, M. G., eds.). Nat. Mus. Wales Geol. Ser., 9, 158-170.

Bergström, S. M., Huff, W. D., Kolata, D. R. \& Bauert, H. 1995. Nomenclature, stratigraphy, chemical fingerprinting and areal distribution of some Middle Ordovician K-bentonites in Baltoscandia. Geol. Fören. Stockh. Förh., 117, 1-13.

Bergström, S. M., Huff, W. D., Kolata, D. R. \& Kaljo, D. 1992. Silurian K-bentonites in Iapetus Region: A preliminary event-stratigraphic and tectonomagmatic assessment. Geol. Fören. Stockh. Förh., 114, 327-334.

Berry, W. B. N., Wilde, P. \& Quinby-Hunt, M. S. 1989. Palaeozoic (Cambrian through Devonian) anoxitropic biotopes. Palaeo. Palaeo. Palaeo., 74, 3-13.

Brusewitz, A. M. 1986. Chemical and physical properties of Paleozoic potassium bentonites from Kinnekulle, Sweden. Clays and Clay Minerals, 34, 442-454.

Byström, A. M. 1956. Mineralogy of the Ordovician bentonite beds at Kinnekulle, Sweden. Sver. Geol. Undersökn., Ser. C, No. 540, 1-62.

Byström, A. M. 1957. The clay minerals in the Ordovician bentonite beds in Billingen, south-west Sweden. Geol. Fören. Stockh. Förh., 79, 52-56.

Grim, R. E. \& Güven, N. 1978. Bentonites: Geology, Mineralogy, Properties and Uses. Developments in Sedimentology, 24. Elsevier, Amsterdam.

Hageman, F. \& Spjeldnaes, N. 1955. The middle Ordovician of Oslo region, Norway. 6. Notes on bentonites (K-bentonites) from the Oslo-Asker district. Norsk Geologisk Tidskrift., 35, 2952.

Hay, R. L., Lee, M., Kolata, D. R., Matthews, J. C. \& Morton, J. P. 1988. Episodic potassic diagenesis of Ordovician tuffs in the Mississippi Valley area. Geology, 16, 743-747.

Helgeson, H. C. \& Mackenzie, F. T. 1970. Silicate - sea water equilibria in the ocean system. Deepsea Research, 17, 877-892.

Jürgenson, E. 1958a. Metabentonites in Estonian S.S.R. In Geoloogia Instituudi Uurimused, II. Eesti Riiklik Kirjastus, Tallinn, 73-85 (in Russian).

Jürgenson, E. 1958b. Forms of silica in Ordovician and Silurian carbonate rocks in Soviet Estonia. In Geoloogia Instituudi Uurimused, II. Eesti Riiklik Kirjastus, Tallinn, 87-92 (in Russian).

Jürgenson, E. 1962. Sediments of volcanic origin in Estonian bedrocks. Eesti Loodus, 229-230.

Jürgenson, E. 1964. Silurian metabentonites of Estonian S.S.R. In Litologiya paleozojskikh otlozhenij Estonii. Institut Geologii, Tallinn, 87-100 (in Russian).

Jürgenson, E. 1966. Lithology of Llandoverian Beds in Estonia. Tallinn (in Russian).

Jürgenson, E. 1977. Vtorichnoe okremnenie karbonatnykh porod, svyazannoe s metabentonitovymi prosloyami drevnego paleozoya Estonii. In Opyt izucheniya vtorichnykh izmenenii $v$ karbonatnykh porodakh Pribaltiki $i$ Belorussii. Tallinn, 39-40 (in Russian).

Jürgenson, E. 1988. Deposition of the Silurian Beds in the Baltic. Valgus, Tallinn (in Russian).

Kepezhinskas, K., Lashkovas, J. \& Shimkevichius, P. 1994. The Ordovician metabentonites of the Baltic region as a reflection of volcanic activity in the Iapetus palaeoocean and Tornquist Sea. Geologija (Lituaniae Acad. Sci.), 16, 34-42. 
Kiipli, E. \& Kallaste, T. 1996. Geochemical characterization of some Estonian metabentonites. Proc. Acad. Sci. Estonia. Geol., 45, 2, 68-77.

Lapinskas, P. P. 1965. Metabentonity nizhnego silura Litvy. In Geologiya i neftenosnost' paleozoya Yuzhnoj Pribaltiki. Tr. In.-ta geol., 1. Vilnius, 49-63 (in Russian).

Laufeld, S. \& Jeppsson, L. 1976. Silicification and bentonites in the Silurian of Gotland. Geol. Fören. Stockh. Förh., 98, 31-44.

Manheim, F. T. 1961. A geochemical profile in the Baltic Sea. Geochim. Cosmochim. Acta, 25, 52-70.

Marshall, W. L. \& Warakomsky, J. M. 1980. Amorphous silica solubilities - II. Effect of aqueous salt solutions at $25^{\circ} \mathrm{C}$. Geochim. Cosmochim. Acta, 44, 915-924.

Nestor, H. 1990. Basin development and facies models. In Field meeting, Estonia 1990. An Excursion Guidebook (Kaljo, D. \& Nestor, H., eds.). Inst. Geol. Estonian Acad. Sci., Tallinn, 33-36.

Park, K. 1966. Deep-sea pH. Science, 154, 1540-1542.

Park, K. 1968. Seawater hydrogen-ion concentration: vertical distribution. Science, 162, 357-358.

Railsback, L. B. 1990. Influence of changing deep ocean circulation on the Phanerozoic oxygen isotopic record. Geochim. Cosmochim. Acta, 54, 1501-509.

Railsback, L. B., Ackerly, S. C., Anderson, Th. F. \& Cisne, J. L. 1990. Palaeontological and isotope evidence for warm saline deep waters in Ordovician oceans. Nature, 343, 156-159.

Snäll, S. 1978. Silurian and Ordovician bentonites of Gotland (Sweden). Stockholm Contributions in Geology, 31, 1-79.

Utsal, K. \& Jürgenson, E. 1971. The mineralogy of Estonian metabentonites. Eesti NSV TA Toim. Keemia, Geol., 20, 4, 336-348 (in Russian).

Velde, B. \& Brusewitz, A. M. 1982. Metasomatic and non-metasomatic low grade metamorphism of Ordovician metabentonites in Sweden. Geochim. Cosmochim. Acta, 46, 447-452.

Vingisaar, P. A. 1972. On the distribution of the main metabentonite stratum (d; XXII) in the Middle Ordovician of Baltoscandia. Eesti NSV TA Toim. Keemia, Geol., 21, 2, $62-70$ (in Russian).

Vingisaar, P. \& Murnikova, T. 1973. New data on the mineralogy of some Estonian Lower Caradocian metabentonites. Eesti NSV TA Toim. Keemia, Geol., 22, 2, 149-158 (in Russian).

Voitkevitch, G. V. \& Zakrutkin, V. V. 1976. Osnovy geokhimii. Vysshaya shkola, Moskva (in Russian).

Winchester, J. A. \& Floyd, P. A. 1977. Geochemical discrimination of different magma series and their differentiation products using immobile elements. Chemical Geology, 20, 325-343.

\title{
METABENTONIITIDE KOOSTISE SÕLTUVUS SETTEKESKKONNAST (FAATSIESTEST) EESTI ALAMSILURIS
}

\author{
Tarmo KIIPLI, Enli KIIPLI ja Toivo KALLASTE
}

Llandovery ja Wenlocki ealisi vulkaanilise tuha kihte on uuritud röntgendifraktomeetria ja röntgenfluorestsentsanalüüsiga. Ümberkristalliseerunud tuha koostis varieerub suurel määral alates peaaegu monomineraalsetest K-päevakivi, illiit-smektiiti või kaoliniiti sisaldavatest erimitest kuni nende mineraalide segudeni erinevates vahekordades. $\mathrm{K}_{2} \mathrm{O}$ sisaldus on 3,6-15,3\% ja $\mathrm{Al}_{2} \mathrm{O}_{3}$ oma $18-31 \%$. Seesugune variatsioon erineb suuresti võimaliku lähtemagma koostisest. Ilmnes 
selge sõltuvus metabentoniitide koostise ja siluri šelfimere faatsieste vahel. Kaoliniidi olemasolu sügava šelfi piirkonnas tõestab madalat $\mathrm{pH}$ taset (alla 7,4) põhjalähedases vees. K-päevakivi on moodustunud madalaveelise šelfi alal - seal oli $\mathrm{pH}$ niisama kõrge $(7,8-8,2)$ nagu tänapäevase merevee oma.

\section{СОСТАВ МЕТАБЕНТОНИТОВ В ЗАВИСИМОСТИ ОТ ОСАДОЧНЫХ ФАЦИЙ В НИЖНЕМ СИЛУРЕ ЭСТОНИИ}

Тармо КИЙПЛИ, Энли КИЙПЛИ и Тойво КАЛЛАСТЕ

С помощью рентгенофрактометрического и рентгенофлюоресцентного методов изучены лландоверийские и венлокские прослои вулканического пепла (метабентониты). Установлено, что состав перекристаллизованного пепла существенно варьирует начиная с почти мономинеральных калиевого полевого шпата, иллит-смектита или каолинитсодержащих разновидностей и кончая смесями этих минералов в различных соотношениях. Содержание $\mathrm{K}_{2} \mathrm{O}$ составляет $3,6-15,3 \%$ и $\mathrm{Al}_{2} \mathrm{O}_{3}-18-31 \%$, т. е. в процентном отношении оно значительно отличается от предполагаемого в исходном пирокластическом материале. Выявилась также зависимость между составом метабентонитов и фациями силурийского шельфового моря. Можно думать, что низкие значения $\mathrm{pH}($ ниже 7,4$)$ обусловили образование каолинита в осадках глубокого шельфа. В условиях мелководного шельфа, где шло образование аутигенного калиевого полевого шпата, воды были более щелочными $(\mathrm{pH} 7,8-8,2)$, т. е. $\mathrm{pH}$ была близкой или аналогичной $\mathrm{pH}$ современных морей и океанов. 